DOI: https://doi.org/10.32839/2304-5809/2019-1-65-29

UDC 821.111-342(71)

Chernova Yuliia

Petro Mohyla Black Sea National University

\title{
THE GENRE OF CANADIAN SHORT STORY
}

Summary. The article emphasizes the genre of the short story in Canadian literature and is based on such short stories as Reunion by Guy Vanderhaeghe, The Loons by Margaret Laurence and Identity by Clark Blaise. The analysis of each story begins with short data about the author and continues by underlining details of the stories as the distinctive style of the author. Psychological peculiarities of each author's writing are discussed. Besides, the scientific article provides the list of the most eminent figures in Canadian literature, both prose writers and poets. The short list of the researchers who have analyzed the same issue is also submitted.

Keywords: Canadian literature, Guy Vanderhaeghe, Margaret Laurence, Clark Blaise, short story, genre.

Чернова Ю.В.

Чорноморський національний університет імені Петра Могили

\section{ЖАНР КОРОТКОГО КАНАДСЬКОГО ОПОВІДАННЯ}

Анотація. Стаття робить акцент на жанрі короткого канадського оповідання та написана на матеріалі трьох коротких розповідей: "Reunion” («Сімейна зустріч») Гі Вандергеге, “The Loons” («Гагари») Маргарет Лоуренс та "Identity” («собистість) Кларка Блеза. Аналіз кожного оповідання розпочинається зі стислої інформації про автора та продовжуеться підкресленням деталей як характерного стилю письменника. Психологічні особливості письма кожного автора також обговорюються. Крім того, наукова стаття надає список найбільш видатних постатей у канадській літературі, як прозаїків, так і поетів. Короткий список дослідників, які аналізували цей жанр, також надаеться.

Ключові слова: канадська література, Гі Вандергеге, Маргарет Лоуренс, Кларк Блез, коротке оповідання, жанр.

The definition of the problem. Canadian literature is little known for Ukrainian students, usually the question "What Canadian writers are you capable of naming?" is never answered by the audience. It evokes indignation among researchers who analyze literature tradition of Canada, after all the works belonging to it are characterized by a kind of unique "cold" distinctness that reveal everyday mundane problems which in their turn are familiar to many of the reading audience. It is worth of mentioning such eminent Canadian novelists as Lucy Maud Montgomery (1874-1942), Robertson Davies (1913-1995), Margaret Atwood (born in 1939), Mordecai Richler (1931-2001), Margaret Laurence (1926-1987), Timothy Findley (1930-2002), Rudy Wiebe (born in 1934), Rohintron Mistry (born in 1952), Farley Mowat (1921-2014), Michael Ondaatje (born in 1943), Carol Shields (1935-2003), Lawrence Hill (born in 1957), Yann Martel (born in 1963), whose oeuvre is known and respected all over the world, translated in many languages, celebrated with many prestigious awards and mostly dramatized. Speaking about Canadian poetry we are fully entitled to mention Margaret Atwood and Michael Ondaatje again and moreover to add Leonard Cohen (1934-2016), Anne Carson (born in 1950), Al Purdy (1918-2000), Earle Birney (1904-1995), Patrick Lane (born in 1939), Margaret Avison (1918-2007), Barry Phillip Nichol (1944-1988). Further still one ought to distinguish the genre of a short story, the most outstanding representative of which in Canada is Alice Munro (born in 1931), who was the first in her country to win the Nobel prize and is already deservedly and justly called Canadian Chekhov.

The researchers that analyzed the material. Canadian short story was discussed by Gerald Lynch and Angela Arnold Robbeson in their Essays on the Canadian Short Story, W.J. Keith, Alistair MacLeod in his essay "The Canadian Short Story", Katarina Korosiova in her Master's Diploma Thesis "The Canadian Short Story".

The part of the problem usually not solved. The position of the inexperienced that a short story is much easier as a literature genre is absolutely wrong, after all an author on the contrary faces a rather complicated target of conveying a story with all details and descriptions not within a long novel but through brief ten or fifteen pages.

The aim of the article. What are the characteristics of Canadian short story? What other Canadian authors achieved success in this genre besides Alice Munro? We decided to base the research of this matter on three stories such as Reunion by Guy Vanderhaeghe, The Loons by Margaret Laurence and Identity by Clark Blaise.

The main part. Reunion was written by Guy Vanderhaeghe, an extremely educated and intelligent man who first of all is famous for his western trilogy, one part of which, The Last Crossing, won in the prestigious annual radio battle Canada Reads, so to say it acquired the status of the title that should be read by all Canada. The story Reunion does not contain any elements of western, the author's favorite style, this is nothing but a psychological outline of the problem which is familiar to every married couple - a meeting with one of the spouse's relatives. In a touching way Vanderhaeghe renders worries of a six-year-old-boy because of his parents' rows, his uncertainty about who he is in reality - Cosgrave or should he use his mother's maiden name? Readers' indignation is evoked by the action of fury from Brian's father when in the heat of the moment Jack Cosgrave throws a stone at his son so that he doesn't follow him. This gesture symbolizes a psychological trauma of a child 
whose parents always argue or then divorce being involved in the tug-of-love and not being able to give their children an opportunity to grow up as a secure person. Vanderhaeghe doesn't indulge in mystery or ambiguity that can appeal to the modern audience being used to reading between lines. On the contrary in Vanderhaeghe's works, unlike for example Margaret Atwood, everything is clear and transparent - there is a conflict and its reason. The writer in the comprehensible way interprets an ancient problem of the married life - quarrels based on different social status, after all Edith is from a well-off family when little could Jack build his own career and occupy some position for a long time. In his special manner Vanderhaeghe explains family ties not only as a supporting power but as something that can sink this family ship. It is always emphasized through all the members of Edith's family when nobody understood her choice of a husband-to-be, when her brothers usually provoke Jack into a fight and her father once didn't support Jack's financial offer. Still Vanderhaeghe depicts his main character as a hero but it should be added that Jack's heroism is a bit ridiculous though it is a characteristic of post-modern world. If once upon a time Edith was absolutely charmed by Jack's charisma and bravery today it is a man abusing alcohol and singing a song that to his mind can be interpreted as an eloquent sign of reconciliation. But this song only makes his wife blush in front of her brother's family.

There is one very specific peculiarity about Canadian literature - authors often to some extent mention Britain, British traditions and mentality, and by doing it writers reveal their negative attitude to the Crown. Great Britain like a red thread is obvious in the last part of The Salterton Trilogy by Robertson Davies. It is not surprising, after all Canada belonged to the British Empire for long with the status of either a colony or Dominion. Britain is also present in the story Reunion where Vanderhaeghe grants his practical and sensible character Edith a very romantic feature - ardent interest to the Royal family that is usually an occasion for Jack to tease his wife. In such famous novels by his as My present Age, Homesick, The Englishman's Boy Guy Vanderhaeghe emphasizes deep issues of the necessity to remember and respect one's past, the influence of setting and time on characters and their fate, attempts to reconcile with the environment for the sake of one's soul. Nevertheless Reunion could be treated as something very close to an average reader, after all psychological pressure and misunderstanding present a wide-spread problem in almost every family at any time.

When a researcher (a teacher) discusses Margaret Laurence's oeuvre they ought to be sure that the audience understands the title of her short story The Loons, as this bird has a very symbolic meaning in it. Laurence is one of the most influential figures in Canadian literature. All her characters are familiar to a reader because they go through the same life hardships. Living with her husband in Africa did the authoress publish her collection of the translation of Somalian folklore "A Tree of Poverty", the first one of such a kind in the world. Laurence is popular with such novels as This Side Jordan, The Stone Angel, A Jest of God, The Fire-Dwellers and The Diviners. On her pages the writer creates an imaginary town of Manawaka and makes it inherent in the characters' life. The Loons is not an exception either, the story is told by a girl Vanessa and at the beginning a reader has the wrong impression that the narrator is a boy. Vanessa's family has the Tonnerres, half native Red Indians and half French immigrants, as neighbors. Vanessa's father, a doctor, cared about Tonnerre's daughter Piquette when she was ill with tuberculosis. Since Piquette was the only one woman in her family after her mother had disappeared the household was absolutely on her weak shoulders, even though at the beginning of the narration she is only thirteen. In order to help the girl recover after a serious disease Vanessa's father offers his wife to invite Piquette to their summer cottage. Just there Vanessa's attempts to establish friendly relationship with Piquette took place, even though they were not successful as Piquette was a rude and aloof girl. In summers Vanessa and her father enjoyed walking to the local pier where at night they would listen to the cries of loons. As a bit further Laurence shows, these birds present a symbol of local Red Indians of Canada who were made to leave their native lands. After the unsuccessful marriage Piquette dies with two children in the fire. Years later Vanessa comes to the pier again and sees that it was reconstructed by the authorities much time ago. She doesn't hear loons anymore and understands that they vanished as Piquette did - under the pressure of circumstances. Vanessa makes a conclusion that Piquette was the only one who really understood those birds, so far she got the same unhappy fate. As a skillful psychologist Margaret Laurence underlines that one's behavior can be nothing but a mask, that somewhere inside one has a weak and fragile personality. Just once Vanessa has a chance to see real Piquette's feelings when the girls by chance meet at the bar and Piquette remembers Vanessa's father in a very warm way. Having combined yesterday and today Laurence shows the way longing for happiness can destroy a person and their life.

Clark Blaise (born in 1940) is a Canadian and American writer who was born in the family of Canadians with European background who lived in the USA. The family was always moving and the boy studied at twenty five schools. In 1966 Blaise moved to Montreal and was granted Canadian citizenship but the writer's wife Bharati Mukherjee felt absolutely odd in this country because, as she said, of racism(she was born in India and had Bengali origin). Thus the couple came back to the States in 1980. Besides collections of short stories, memoirs and documental prose (the last was written with his wife) Blaise is famous for such novels as Lunar Attractions, Lusts, If I Were Me.

From the very beginning one feels autobiographical elements in the story Identity by Clark Blaise, after all, the author's father was often an archetype of his paternal characters. The story Identity deliberately mixes the setting and the time, here the protagonist Philip Porter is still a little boy who falls out of an armchair and breaks his arm, and now his is already an adolescent trying to fit the antenna on the roof. Philip's memories are absolutely confused as well, a reader is not able to understand what part is not a lie, the main character himself 
admits that the memories from his childhood can't be reliable. Philip thinks that being a child he often saw his father reading and writing in a Queen Anne chair, but then he remembers that his father was illiterate and there was never such a kind of furniture in their house. Surprisingly enough the most unusual and flamboyant character of this story is not Philip's father and not even his best friend, but his best friend's mother. The woman brought him up alone working as either a waitress or a club hostess. When she came back home from work almost in the morning she paid attention to her appearance and rest only and usually forgot about her son. The writer shows that women ought to treat children's upbringing in a very responsible way, after all changing one's lingerie in front of Peter made him interested in a female body rather early.

As Robertson Davies fills his late works with Jung's psychology Clark Blaise lets Freud in his short story Identity when once after school Philip watches his mother and realizes that she is attractive. Still the boy interprets sexiness in his own specific way - this phenomenon is very close to untidiness. It happened to both the author and his character - they left everything behind and moved to Montreal. Philip didn't know any certain reason of it and can't understand why his parents ask him to forget their real surname. Blaise lets his audience guess and make up any reason they want, the range can be really wide - from debts and lovers to criminal activities. Childhood never leaves a person, we all acquire our fears in it, Clark Blaise is not an exception either, all his worries were conveyed through his character Philip Porter who has already lost his name and is nobody on the border of Canada.

The conclusion. Canadian short story is emotionally full and worries described in it are close to every reader, after all giving material for one's thought and an occasion for deeper self-analysis. The structure of the genre itself already questions the existence of a tangible reality or alludes to the fragmented structure of society. If this genre is combined with topics that address the same subjects, the effect could be really mighty.

\section{References:}

1. Vanderhaeghe, G. Reunion // The Norton Anthology of Short Fiction / R.V. Cassill. - $5^{\text {th }}$ ed., p. 1547-1557.

2. Laurence, M. The Loons // The Norton Anthology of Short Fiction / R.V. Cassill. - $5^{\text {th }}$ ed., p. 930-938.

3. Gordon, R. Robertson Davies' Fifth Business and "That Old Fantastical Duke of Dark Corners, C.G. Jung" // The Canadian Novel: A Critical Anthology, Volume 1 / edited by John Moss. NC Press Limited.

4. Blaise, C. Identity // The Norton Anthology of Short Fiction / R.V. Cassill. $-5^{\text {th }}$ ed., p. 82-90.

5. New, W.H. A History of Canadian Literature. McGuill-Queen's University Press. 